\title{
AJA MÕISTESTAMINE PATAU SÜNDROOMIGA SUBJEKTI SUHTLUSES
}

\section{Ingrid Rummo, Silvi Tenjes}

Ülevaade. Suhtlusandmete analüüsile tuginedes uuritakse artiklis Patau sündroomi mosaiikvariandiga subjekti AJA mõistestamist. Analüüsitakse, kuidas seda abstraktset mõistet suhtluses väljendatakse ning tehakse kindlaks, milline on käeliigutuse roll tähenduse esiletoomisel. Pööratakse tähelepanu tagasiside ja koostöö olulisusele dialoogiprotsessis. Teoreetilised alused lähtuvad interpersonaalse kommunikatsiooni, sh verbaalse ja mitteverbaalse käitumise, aga ka kognitsiooni uuringutest. Suhtlusmodaalsuste, eelkõige käežestide mehhanismide kirjeldamisel lähtutakse klassikaliselt semiootilise märgikategooria aluselt (C. S. Peirce). Patau sündroomi mosaiikvariant on komplitseeritud oma suhtlusmodaalsuste kasutamise võime poolest. Materjali analüüsist selgub, et subjektil on AJA mõistest arusaamise ja mõiste väljendamise võime.*

Võtmesõnad: diskursusanalüüs, interpersonaalne kommunikatsioon, suhtlus, mittesõnaline keel, kognitsioon, kõnekahjustused, Patau sündroomi mosaiikvariant

\section{Sissejuhatus}

Meie uurimus tõukub küsimusest "Kas kontsepti struktuur sisaldab ka ikoonilis-liigutuslikku sisu?" Meid huvitab, milline on seos väljendusmodaalsuse ning tähendusliku ja/või kujundilise seose loomise võime vahel.

Teoreetilised alused lähtuvad interpersonaalse kommunikatsiooni, sh verbaalse ja mitteverbaalse käitumise, aga ka kognitsiooni uuringutest. Tähenduste ja liigutuste tõlgendamisel toetume C. S. Peirce’i seisukohtadest lähtuvale semiootilisele kategoriseerimisele. Teoreetilised alused ja metodoloogia on lähema vaatluse all artikli 2. osas. Töö analüüs on seotud käsitlustega inimese kognitsioonist ja ajauuringutest, samuti ülevaatega tähenduse kontseptualiseerimisest.

* Artikkel on valminud Eesti Teadusfondi grandi 8008 osalisel toel. 
Suhtumine puuetega inimestesse oli kogu nõukogude aja vältel halvustav ja alavääristav. Nüüd on see olukord mingil määral paranenud, kuid teemaga mitte kokku puutunud inimestel on siiski keeruline mõista, et ka näiteks erinevate kõne$\mathrm{ja}$ /või vaimupuuetega inimestel on oma mõtte- ja tundemaailm, soovid ja vajadused, mida teistega jagada. Eestis ei ole veel kõnetute või tugeva kõnepuudega inimeste suhtlusprobleeme teaduslikul tasemel uuritud. Käesolev artikkel püüab sellesse teemasse oma panuse anda.

\section{Teoreetilised alused ja metodoloogia}

Suhtlusuuringud peavad tähtsaks eesmärkide ja teadmiste struktuure, sest inimesed kasutavad vestluses eelteadmisi. Et saavutada soovitud eesmärki, peab suhtlejatel olema teadmisi oma suhtluspartneritest, näiteks nende eelistustest, taustast, harjumustest. Samuti peavad neil olema alusteadmised interaktsiooni protseduuridest ja strateegiatest ning sotsiaalsetest kontekstidest, milles nad suhtlevad.

\subsection{Interpersonaalne kommunikatsioon ja interaktsioon}

Meie uurimistöö alused lähtuvad interpersonaalse kommunikatsiooni uuringute pikast reast. Interpersonaalne suhtlus hõlmab verbaalse ja mitteverbaalse suhtluse ning sotsiaalse interaktsiooni ${ }^{1}$. Interpersonaalse suhtluse teooria ja uuringud püüavad leida ja mõtestada, kuidas inimesed kasutavad verbaalset diskursust ja mitteverbaalseid tegevusi, samuti ka kirjalikku diskursust selleks, et saavutada erinevate vahenditega seotud ja suhtluslikke eesmärke nagu informeerimine, veenmine, emotsionaalse toetuse esilekutsumine jm (Berger 2008: 2473). Interpersonaalset suhtlust on traditsiooniliselt defineeritud kui protsessi, mis leiab aset vahetus suhtluses. Sotsiaalse interaktsiooni valdkonna tõus on kaasa haaranud ka sellised suhtlustehnoloogiad nagu arvuti, mobiiltelefon jm uued võimalused. (Marby 2008: 4677)

Interpersonaalse käitumise uurimise algus paigutub kommunikatsiooniuuringute avaral väljal aega enne Teist maailmasõda, kui Ameerika Ühendriikides, Harvardi ärikoolis, arutati 1920.-30-ndatel sotsiaalse interaktsiooni ja sotsiaalsete suhete teemat ning analüüsiti nende suhete mõju töö tulemuslikkusele kollektiivi sees. 1930-ndatest aastatest pärinevad tänaseni käibel olevad olulised mõisted nagu tagasiside, konflikt, interaktsiooni sekventsid ${ }^{2}$ või sotsiaalsed võrgustikud ${ }^{3}$ (Knapp jt 2002).

Interaktsioon ehk vastasmõjuga suhtlus on suhtlusuuringute keskne mõiste. Enamik uurijaid on seisukohal, et korrektne on pidada seda interaktsiooniprotsessiks - kestvaks, alati muutuvaks sündmuseks. Mõista suhtlusprotsessi tähendab suures osas mõista seda, mis juhtub mingi ajaperioodi jooksul. Interaktsioon võib olla protsess filosoofilises mõttes, kuid uuringute jaoks rakendame vähem radikaalset seisukohta: me võime õppida protsessist, kui jälgime seda teatud ajavahemiku jooksul - fikseerime ja analüüsime suhtlust mitmetel järjestikustel ajahetkedel.

1 Sotsiaalne interaktsioon on (üldistatult) paljude eesmärkide saavutamise "instrument", eesmärgile suunatud tegevus erinevate teadmiste abil (Berger 2002: 205, 181).

2 Lähtutakse ideest, et igasugune vestlus on üles ehitatud sekventsidena, s.t kõnevoor konstrueeritakse nii, et see sobituks eelnevate voorudega, enamasti vahetult eelneva vooruga. Iga lausung loob vestluses konteksti järgmise lausungi jaoks.

3 Mõiste tähendus on tänaseks pisut muutunud tänu uutele tehnoloogiatele. 
Interaktsiooniprotsessi on uuritud ajaliste karakteristikute alusel. Nii kõneleja kui ka kuulaja seisukohast on oluline teada, kui tihti teatud käitumine kindla ajaperioodi jooksul ilmneb. Kõige püsivamalt on uuritud verbaalset ja mitteverbaalset käitumist. Juba 1950-ndatest kasvas mitteverbaalne suund kiiresti. Ainult kõnelise valdkonnaga tegelesid vestlusanalüüsi uurijad. Tänaseks on mõlemad suunad teinud palju tõhusat koostööd ning peamine tähelepanu on nüüd sotsiaalse interaktsiooni uuringutel, signaalide tajumisel, taju ja tunnetusprotsesside seostel käitumuslikkusega. Käitumise kaudu situatsioonis avalduvad inimese kognitiivsed võimed.

\subsection{Kognitsioon suhtlusuuringutes}

Nagu eespool öeldud, suhtleb inimene, indiviid, oma kognitiivsete võimete kaudu. Seega on suhtlusesse hõlmatud kognitsioon - indiviidi võime ümbritsevat tunnetada ja uusi seoseid luua. Üks olulisemaid sellesisulisi teemaarendusi on Varela, Thompsoni ja Roschi (1991: 172) esitatud arutluskäik välismaailma tunnetamisest kui kehastunud kognitsioonist. Kasutades mõistet kehastunud juhivad Varela, Thompson ja Rosch (1991: 173) tähelepanu kahele olulisele asjaolule:

1) kognitsioon sõltub kogemustest, mida inimene omandab oma keha kaudu erinevate sensomotoorsete võimete vahendusel, ja

2) individuaalsed sensomotoorsed võimed on osa laiemast, neid hõlmavast bioloogilisest, psühholoogilisest ja kultuurilisest kontekstist.

Tunded ja mõtted on esialgu olemas vaid ühe inimese "sees", on tema jaoks kehastunud. Suhtluse käigus tulevad nad esile, nende tähendused varieeruvad ja arenevad edasi. Inimesed omandavad informatsiooni sensomotoorsete võimete abil, kuid saavad samas omakorda ka ise, läbi oma kommunikatiivsete tegevuste välismaailma aktiivselt mõjutada ja kontrollida.

Kognitsiooniuuringud on meie töös seotud tajumusliku ajaga (sellest osas 4). Inimkognitsioon seob käitumise mõtlemisega. Mõte meie kogemuse mingist aspektist mõjutab potentsiaalselt käitumist igas interaktsioonis (Knapp jt 2002: 13). Uurimisüksusteks on siin mõtted minast (ingl self), teisest ja situatsioonist. Samas, info viidatava mõtte jaoks korjatakse enne ja/või pärast uuritavat interaktsiooni, harva selle ajal. Tajumusliku info arvestamine suhtlejate kohta on suhtlusuuringutes küllaltki uus faktor. Näiteks mõtted, mis mõjutavad käitumist, võivad olla suhteliselt abstraktsed ('Sõbrad aitavad hädas') või just väga konkreetsed ('Marek võtab alati tagavararatta kaasa'). Kui mõtted mõjutavad käitumist, siis käitumine kujundab omakorda ümber originaalmõtte, aga ka järgnevad mõtted.

\subsection{Kõneliste erivajadustega inimesed suhtluses}

Kõnevõime osalisel puudumisel või selle kaotusel võib olla mitmeid põhjusi. On erinevaid puudeid (sealhulgas geneetilised vaimupuuded), ajukoore kõnekeskuste piirkondade kahjustusi (näiteks afaasiad), millega kõnetus kaasneb. ${ }^{4}$

4 Uuritud on ka teistsuguste erivajadustega inimeste suhtlust, näiteks pimekurdi lapse egotsentrilist kõnet 
Kui inimesel kõnet ei ole või on vaid mõned häälitsused, on väga raske jälile saada, millised on tema keelelised võimed tegelikult. Siin aitavadki suhtlusuurijaid situatsioonide salvestamine audio- ja videovahenditega ning materjali diskursiivne analüüs.

Charles Goodwin on mitmes oma töös (nt Goodwin 1995 ja 2003) uurinud raske afaasia all kannatanud subjekti suhtlust. Afaasia toob endaga kaasa kõne produtseerimise ja/või mõistmise võime kadumise või vähenemise. Põhjuseks on kõneprotsesse juhtivate ajupiirkondade kahjustused. Goodwini uuritud indiviid tegi läbi insuldi, mille tagajärjel jäi ta parem kehapool halvatuks ja ta kaotas oma kõnevõime peaaegu täielikult. Kõneteraapia tulemusena õppis ta uuesti hääldama vaid kolme lühikest ingliskeelset sõna: yes ('jah'), no ('ei') ja and ('ja'). Samas sai uuritav indiviid teiste kõnest aru, oli võimeline vasaku käega žestikuleerima ja kasutama tähendust kandvaid intonatsioone ja hääletoone.

Goodwini $(1995,2003)$ uuritava materjali kaudu on saadud jälile mitmete modaalsuste oskuslikule kombineeritud kasutamisele. Tema uuritav subjekt annab žestide, näoilmete või peaasenditega märku, kas ta vajab oma kaaslaselt mõtete sõnastamisel abi või ei tohi teda hetkel katkestada. Goodwin on oma töös rakendanud vestlusanalüüsi meetodit, toetudes tihti meetodi sellele osale, mis tegeleb parandusmehhanismidega - vestlejad parandavad ja täpsustavad jooksvalt enda või oma partneri(te) öeldut selleks, et tähendust võimalikult täpselt edasi anda. Selline lähenemine on tõukeks meiegi materjali puhul, kuid meie uuritava puhul lisandub liigutuslike modaalsuste (ka manipulatsioonide) analüüs. Läbi süstemaatilise koostöö dialoogis osalejate vahel ehitatakse üles suhtlusüksuse tähendus. Tavaliselt "toodab" lausungi ja seda saatva žesti üks ja seesama inimene ehk see, kes parasjagu räägib. Goodwini näidetest näeme aga, et kõnetu inimese žestidele antakse tähendus tema suhtluspartnerite kõne kaudu, s.t nende toel, kes püüavad kõnetust aru saada.

Mehhanismid, mis lubavad inimesel tähendust luua ja tähendusest kontekstis aru saada, pole kaugeltki veel teaduses lõplikult kindlaks tehtud. Diskursusanalüüsi on kasutatud nii afaasiate kindlakstegemisel kui muudel kliinilistel eesmärkidel (selle kohta vt Müller, Guendouzi, Wilson 2008: 3-31).

\subsection{Uurimuse metodoloogia}

Meie uurimuse metodoloogia koosneb mitmest faasist. Kõigepealt on kogutud analüüsikorpus, uurimistöö alusmaterjal, mille sisu on saadud peamiselt videokaameraga filmides, aga ka osalusvaatlusest ning selle põhjal päevikumärkmete kirjutamisest. Korpus sisaldab 9 tundi 42 minutit videomaterjali, millest oli 2010. aasta lõpu seisuga litereeritud 4 tundi 16 minutit. Teiseks oleme defineerinud analüüsitavate lõikude valiku lähtekriteeriumid. Analüüsiüksuste valik toimub spetsiifiliste suhete kontekstis (suhtluspartner, ümbritsev ruum, manipulaatorid jm). Kolmandaks teostati valitud üksuste kvalitatiivne analüüs, mille esmased tulemused esitame töö analüüsiosas.

Töö eesmärk on leida, millised on Patau-indiviidi võimalused piiratud eneseväljendusvõimete korral ennast arusaadavaks teha ning kuidas ta seda teeb. Kitsam eesmärk on mõista, kuidas Patau sündroomi mosaiikvariandiga subjekt konst- 
rueerib mõistet AEG ning milliste vahenditega AEGA suhtluses edastatakse, kui kõnekeelelised võimed on äärmiselt piiratud. Teise olulise kategooria - RUUMI - mõistestamist oleme lähemalt käsitlenud peatselt ilmuvas töös (Jokinen jt (ilmumas)).

Uuritav indiviid on praeguseks (detsember 2010) 20-aastane. Andmete kogumist alustati 3,5 aastat tagasi. Selles töös on analüüsitud kahte videolõiku, esimese filmimise ajal oli uuritav 17-, teises 18-aastane. Analüüsimeetodiks on salvestatud suhtluse litereerimine Jeffersoni (Sacks jt 1974) transkriptsiooni abil, mida on vastavalt vajadusele kohandatud.

\section{Tähenduse tõlgendamine}

Järgmine oluline küsimus on, kuidas tõlgendada tähendust käitumuslike signaalide kaudu? Seda võib lühidalt vaadata mitme tasandi kaudu: a) teksti ${ }^{5}$ sõnasõnaline sisu, b) reageering/vastamine sellele, kuidas partner eelnevat vastust interpreteeris, c) kindlakstegemine, kuidas partner peaks vastama teatele, d) kas edasist interaktsiooni (nüüd või hiljem) soovitakse jm (Knapp jt 2002). Kuidas interpersonaalses suhtluses mõistetakse tähendust? Kuigi tähenduse tähendusi inimsuhtluses ei eraldata, võib kommunikatsiooniuuringutes näha sellele kolme lähenemist (Littlejohn 1989): strukturaalset, interaktsioonilist ja kognitiivset. Nende eri lähenemiste peamine ühiseesmärk on "lokaliseerida" tähendus ruumis ja ajas ning püüda täpsustada, kuidas tähendus tuleb järk-järgult esile. Sama eesmärk on ka meie uurimistööl.

Tähenduse kajastusi keeleteaduses esitame niivõrd, kuivõrd töös on tegemist arutlusega AJA mõistestamise üle. Viitame vaid kontseptuaalsele ja semiootilisele tähendusele.

\subsection{Kontseptuaalne tähendus}

Tähenduse kontseptuaalsed teooriad on eelkõige seotud inimese n-ö tervemõistuslikkusega. Kontseptuaalse tähenduse erinevatel alateooriatel on ühine eeldus, et kontseptidel on olemas teatud struktuur. Sõna tähendus on struktureeritud idee,

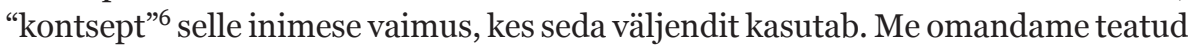
kultuuriruumis üles kasvades tohutu hulga "eelpakitud" (ingl prepackaged) mõisteid sõna-tähenduste vormis (Goddard 1998: 7-8). Kognitiivteadustes on kontseptid üldiselt struktureeritud mentaalsed representatsioonid subpropositsioonilise ${ }^{7}$ (ingl subpropositional) sisuga (Margolis, Laurence 2006: 817). Toolı mõiste on mentaalne representatsioon tooli sisuga. Ta sisaldab mõtteid toolist ja on seotud kategoriseerimisprotsessidega, mis funktsioneerivad määratlejatena (kas miski on tool). Sõna kontseptuaalse tähenduse all mõeldakse sõnaraamatutähendust, mis osutab mõistele. Kontseptuaalset tähendust on alternatiivselt kirjeldatud ka kui kognitiivset ('tunnetuslikku', 'teadmuslikku') või denotatiivset ('tähistavat', 'märkivat') tähendust (vt ka Lyons 1977, 1981).

Kuna meie liigutuste jaotus baseerub Peirce’i semiootilisel kategorisatsioonil, siis käsitleme järgnevalt tähenduse semiootilist lähenemist.

\footnotetext{
Mõeldud on teksti avaras, diskursiivses tähenduses

6 Kontsept - sõna koos tema tähendusega.

Propositsioon on tähenduse see osa, mis sisaldab lauses esitatud "objektiivseid" fakte ja seetõttu võib nõuda tõestust; väide, tees; loogikas: propositsioon.
} 


\subsection{Semiootiline tähendus}

Semiootilist tähenduse käsitlust nimetatakse ka tõlkeliseks (ingl translational) (Goddard 1998: 10). Kuni me suhtleme tähendustes isegi siis, kui me püüame neist rääkida, ei saa me semiootilise vaate järgi kunagi põgeneda keele eest (Goddard 1998: 10). See ei tähenda, et me ei saa kirjeldada ja analüüsida konkreetseid tähendusi. Tõsi, me ei saa minna väljaspoole tähendusväljendite süsteemi ega taandada tähendusi millekski muuks (individuaalsed ideed, ajulainete mustrid, müstilised Platoni vormid, kasutusmustrid jms). Kui me tahame kirjeldada mingi keeleväljendi tähendust, pole meil muud valikut, kui teha seda teiste keeleväljendite tähenduste terminites. Ja miks ka mitte? On ju tundmatu sõna tähenduse seletamiseks alati võimalik teha seda tuntud sõnade seletamise kaudu. "Tõlkeline" on lähenemine seepärast, et keeleväljendi tähendust peetakse teatud mõttes tõlkeks, s.t me anname väljendile tähenduse teise väljendisse tõlkimise kaudu. "Semiootiliseks" nimetatakse seda seepärast, et semiootika suhtub "märkide” maailma kui taandamatusse. (Goddard 1998) C. S. Peirce (1839-1914), Ameerika loogik ja filosoof, on rõhutanud "märgi taandamatust". Peirce'i üks peamistest seisukohtadest (Peirce 1931-1958, 2: 230) väidabki, et on võimatu taandada märki mingitele elementidele, mis ise ei ole märgid.

Peirce’i huvitas, kuidas märk on seotud objektiga, mida ta tähistab. Sellest sündis rida liigitusi, kuid tänaseni on kõige fundamentaalsemaks jäänud tema nn teine trihhotoomia. Selle järgi on kõik märgid jaotatud kolme tüüpi: ikoonid, indeksid ja sümbolid. (Lotman 2002: 519) Ikooniline märk on seotud objektiga läbi tema sarnasuse (nt visuaalsed märgid, mis osutavad meeste ja naiste tualettruumidele, on ikoonid; onu foto on onu ikoon jne). Indeksiline märk on seotud tähistatava objektiga läbi ruumilise suhte, Peirce’i järgi läbi reaalsuse (nt suits on tule indeks, viitab tulele ja näitab selle asukohta). Sümboliline märk on seotud oma objektiga üksnes kokkuleppe alusel, Peirce’i järgi määratud reegli või definitsiooniga. Kõige harjumuspärasemateks sümboliteks on loomuliku keele sõnad. Selles töös me ei lasku Peirce’i märgi olemuse tihedatesse aruteludesse, mainime vaid, et eespool nimetatud keeleväljendi tähenduse seletus ainult teise väljendi kaudu põhineb ideel, et sõnaga kui semioosise lähtepunktiga saame tähistada ükskõik mida, kuid sõna ennast ei saa millegi muuga tähistada kui sõnaga.

\subsection{Ikoonilisus ja žestid suhtluses}

Ikooni, indeksi ja sümboli mõistete kasutamisega järgime Peirce’i märkide klassifikatsiooni kõige üldisemal moel. Ikoonilised ja indeksilised dimensioonid on eelkõige mitteverbaalsed, aga sümbolilised dimensioonid on primaarselt verbaalsed (Hirsch 1995: 14). Samas, primaarne vahend suhtluseks näiteks kurtidel on märgikeel, kus nad kasutavad tähenduse esiletoomiseks žeste. Peirce’ijärgi kuuluvad kolm aluseks olevat semiootilist dimensiooni - ikooniline, indeksiline ja sümboliline - teadmise või kognitsiooni alla (Hirsch 1995).

Ikoonilisust peetakse inimese suhtlusmodaalsuse aluseks (vt nt Koch 2002, Itkonen 2005). Suhtluspilt ise on kirevam ega piirdu ainult ikoonilisusega. Näiteks ütleb Itkonen, et inimesel on kasutada neli aluseksolevat füüsikalist dimensiooni: 
vertikaalne, horisontaalne, diagonaalne ja ajaline. Kõnelemine leiab aset ühes baasdimensioonis - ajas (Itkonen 2005: 114-115). Kui kõnemodaalsus praktiliselt puudub, kasutatakse alternatiivseid modaalsusi (nt žestid).

Kui žest on seotud keele ikoonilise dimensiooniga ja tähendusega erineval viisil (selle kohta vt ka Kendon 1995, 2004, McNeill 1992, Streeck, Knapp 1992 jpt), kas võib ta siis esineda suulise keele võimest lahus, olles seotud inimese kognitiivsete võimetega? Meie analüüs annab võimaluse sellega arvestada (vt situatsioon 1 ja 2), kus AJA tähendus tuleb esile suhtlejate koostöö ja käežestide kaudu.

Ikooniline žest kujutab oma vormiga mõne (kirjeldatava) tegevuse, sündmuse või objekti jooni. Žestid, mida suhtluses kasutatakse, on kahtlemata suhtluslikud oma funktsioonilt ning kujundlikud oma vormilt. Me nimetame neid kommunikatiiuseteks žestideks (selle kohta vt ka Bavelas jt 1992, Bavelas 1994, Bavelas jt 1995, Goodwin 1995 jt), millel on semiootiline (suhtlus)dimensiooniline alus (vt Peirce).

Kuna meie uurimuse fookuses on kõnetu inimese suhtlemisvõimaluste selgitamine tema AJA mõiste esiletoomise kaudu, läheme edasi aja käsitluste teemaga.

\section{Aja käsitlused}

Aja ${ }^{8}$ uurimisega tegeleb kroneemika - teadus, mis uurib inimese ajalisusega seotud mõisteid ja protsesse ning ajalisi seoseid, niivõrd kui inimkommunikatsioon toimub ajalistes raamides (Bruneau 2009: 96). Kroneemika on mitteverbaalse suhtluse uuringute kõige uuem ala ning näib, et see uus fookus ühendab esimest korda kõik ülejäänud mitteverbaalse suhtluse modaalsused. Kõik mittekõnelised kommunikatiivsed teated sisaldavad oma ajafaktoreid, nt midagi, mis toimub enne, ja see, mis tuleb pärast. Me oleme ajalised/ajalikud inimesed (Homo temporalis); meil on kompleksne ajaidentiteet, segu üksikisiku tasandil omandatud erinevatest ajakogemustest. Ajauurijad jagavad valdkonna kaheks: on objektiivne ja subjektiivne aeg. Subjektiivne ehk personaalne aeg jaguneb omakorda neljaks osaks. Peatume järgnevalt vaid neil osadel, mis on töö seisukohast olulisemad (detailsemalt vt Bruneau 2009).

Objektiivne aeg puudutab inimese käitumist seoses ajamõõtmisvahendite ja kalendritega. Need vahendid on seotud meie suhtlussündmuste organiseerimisega ja meie igapäevaste tegemiste ajastamisega. Enamik meist järgib oma harjumuspärast päevakava rutiinselt ja regulaarselt. Me oleme loonud aja “sammulugejaid”, et oma igapäevaeluga toime tulla. Ajamõõduseadmed aitavad inimestel oma personaalset aega reguleerida ja koordineerida seda sotsiokultuurilise ajakäsitluse, tempo ja rütmiga. Objektiivse aja kasutus on tasakaalus subjektiivse ehk personaalse aja kasutusega.

Inimese individuaalsusega seostuval subjektiivsel ajal on mitu tahku. Meie uurimuse seisukohast on oluline tajumuslik aeg, kuna just see on interpersonaalse kommunikatsiooni ja sotsiaalse interaktsiooni lahutamatu osa.

1) Geneetiline ja bioloogiline aeg - uuringud on näidanud, et igas geenis sisaldub ajamääramise struktuur, mille kontrollkellad (ingl control clocks) tagavad stabiilsuse ja üleminekukellad (transient clocks) osutavad

8 Eesti keeles on ilmunud Stefan Kleini populaarne käsitlus “Aeg. Aine, millest koosneb elu” (2009). 
muudatustele (Bruneau 2009: 98). Igaühel meist on oma unikaalne bioloogiline aeg, sest see on esivanematelt päritav. Geneetiline aeg puudutab inimgeenide seisundite ja protsesside vastasmõju. Bioloogilised variatsioonid on alati olemas, kuid tihti on nad alateadlikud, mõjutades meid saatjatena ja vastuvõtjatena suhtlusprotsessides. Bioloogiline aeg sisaldab bioloogilisi rütme, impulsse ja meie bioloogilistest vajadustest tulenevate pingete korraldamist. Kui kahe inimese bioloogilised protsessid on väga erinevad, siis see mõjutab suhtluses ka nende tähelepanu ja tajusid.

2) Tajumuslik aeg puudutab meie mitteverbaalsete vihjete ehk signaalide saatmist. Signaliseeritud suhtluse all mõeldakse seda, kuidas meie aju teiste suhtlust "vastu võtab". Sellist suhtlemist on tihti nimetatud semiootiliseks. Aju võtab vastu signaale, mida tekitavad erinevad loomulikud, füüsilised, tehnilised ja sotsiaalsed keskkonnad. Me töötame läbi valguslaineid (nägemine), helilaineid (kuulmine), rõhulaineid (kompimine), molekulaarseid (haistmine), biokeemilisi laineid (maitsmine) ja teisi rütmilisi stiimulsisendeid. Lained konverteeritakse ja kanaliseeritakse sensoorselt meie ajju.

Tähendusi ei kanta üle otse: üle kantakse ainult mitteverbaalsed sõnumid ehk signaalid, tajumuslik aeg, ajalised jaotused ja tempod. Kui sõnumite mitteverbaalne ehk signaliseeritud külg on interpreteeritud ja representeeritavaks muudetud, on meil tegemist tähenduste ja psühholoogilise ajaga.

3) Psühholoogiline aeg - inimaju ei tugine ainult bioloogilistele ja keemilistele koodidele või mitteverbaalsetele signaalidele, vaid see puudutab ka mälestusi (me nimetame seda minevikuks), tähelepanu ja taju (olevik) ja ootusi (tulevik) ning ajasüsteemi. Inimaju on ajaline organ, mis ulatub läbi meie kehade ja mida meie meeled projitseerivad paljudesse keskkondadesse. Järgnevalt käsitleme seda, kuidas edastab või kuidas moodustab AJA mõistet kromosoomhäirega subjekt.

\section{Patau sündroom}

Kuidas toimib interaktsioon siis, kui indiviidi kõnevõime on tugevasti kahjustunud? Selle kindlakstegemiseks oleme uurinud indiviidi suhtlust, kellel on Patau sündroomi mosaiikvariant. Patau sündroom ehk trisoomia 13 on kromosoomianomaalia. ${ }^{9}$ Kromosoomianomaalia ehk -haiguse all peetakse silmas patoloogiat, mille põhjuseks on kromosoomide arvu või struktuuri muutus. Inimesel on 23 kromosoomipaari, see tähendab, et normaaljuhul on igaühel kokku 46 kromosoomi. Trisoomiate kui autosoomide arvuanomaaliate korral esineb mõne paari asemel tegelikult kolmik. Kõige levinum (umbes 1 juht 800 vastsündinu kohta) on Downi sündroom, mille puhul on tekkinud lisakoopia 21. kromosoomist. Edwardsi sündroom $(+18)^{10}$ esineb sagedusega 1:60oo, Patau $(+13)^{11}$ on kõige haruldasem, "vaid" 1:12 ooo vastsündinu kohta. Kromosoomianomaalia mosaiikvariandi korral, nagu uuritaval juhtumil, on mõned rakud terved, mõned haigusest mõjutatud, seisundi raskusaste võib olla väga erinev ja suur osa tüüpilistest sümptomitest üldse puu-

\footnotetext{
9 Patau sündroomi mosaiikversioon on rahvusvahelises haiguste klassifikatsiooni praegu kehtivas 10 . versioonis (RHK-10, ingl ICD-10) tähistatud koodiga Q 91.5. Vt http://www2.sm.ee/rhk/index.asp (03.03.2011).

10 Edwardsi sündroom (+18) - lisakoopia on tekkinud 18. kromosoomist.

11 Patau (+13) - lisakoopia on tekkinud 13. kromosoomist.
} 
duda. Kuna Patau sündroomi mosaiikvariandi diagnoosimine on keeruline, on seda väga vähe uuritud ja meditsiinikirjanduses vaid harvadel juhtudel kirjeldatud.

Meie poolt uuritava subjekti puhul kaasneb alakõne, mis väljendub ekspressiivse kõne häirena - inimene küll mõistab talle adresseeritud juttu, kuid tema võimalused ennast suulise keele abil väljendada on piiratud. Mitteverbaalsete märkide loome- ja kasutamisvõime võib selliste indiviidide puhul olla säilinud.

Suur osa subjekti suhtlusest toimub žestide ja eesti viipekeele lihtsustatud viibete abil. Oluline roll on näomiimikal ja häälega kaasneval prosoodial, eriti intonatsioonil. Hääl tuleb esile sedavõrd, kuivõrd subjekti suulises kõnes on olemas mõned lihtsustatud sõnad. Lihtsustustes on märgata, et välditud on hääleorganite tugeva pingutusega moodustatavaid konsonante, kõige suupärasemad on olnud labiaalid $m$ ja $b$, samuti $v$. Vokaalid on kõik esindatud ja kasutuses.

\subsection{Situatsioon 1: materjali esitamine}

Dialoog toimus 2007. aasta juunis (kuu nimetus on siinkohal eriti oluline!), kui N oli 17-aastane. Suhtlusest võtavad osa subjekt (N), tema vend (V) ja nende ema (E). (Ema filmib, mistõttu teda salvestatud materjalil näha ei ole, kuid tema häält on kuulda.) Videolôik on 33 sekundit pikk, selle täispikkuses litereering sisaldab 19 lausungit.

(1) $1 \mathrm{E}$ : mis kuupäev täna on

$2 \mathrm{~N}$ : appil ?

(( Näitab pika nina märki ja naeratab. ))

Tõlge: aprill

3 V: \$aprill\$

4 E: j(h)aa aga tegelikult mitmes juuni on

$5 \mathrm{~N}$ : (( Naeratab naljast aru saades, lükkab juukseid üle pea. ))

$6 \mathrm{~N}$ : (( Keerab korraks natuke pead, näitab, et ta mõtleb. ))

$7 \mathrm{E}$ : kuusteist jah

$8 \mathrm{E}$ : kuusteist juuni

$9 \mathrm{~N}$ : (( noogutab ))

$10 \mathrm{E}$ : ei ole aprill $\mathrm{N}$

$11 \mathrm{~N}$ : (( Vaatab otsa, mõtleb, naeratab. ))

$12 \mathrm{E}$ : ütle aprill uuesti

$13 \mathrm{~N}$ : appil ?

(( Näitab pikka nina ja naeratab. ))

Tõlge: aprill

$14 \mathrm{E}$ : aga sa ütlesid mai ka

$15 \mathrm{E}$ : kuidas sa mai ütled

$16 \mathrm{~N}$ : ai ?

$17 \mathrm{E}$ : mai ?

$18 \mathrm{~N}$ : ai

(( Näitab pikka nina. ))

$19 \mathrm{E}$ : siis sa ei pea ju pikka nina näitama kui mai on

(( N hakkab kaamera poole jalutama. )) 
$\mathrm{N}$ teeb analüüsitavas lõigus voorudes 2 ja 18 ligikaudu järgmise viipe ${ }^{12}$ (vt joonis 1):

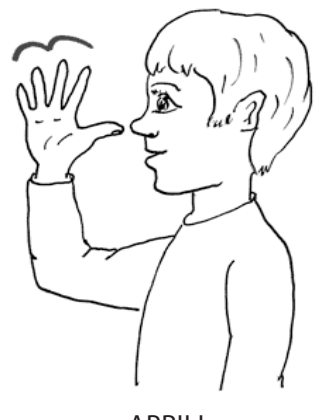

APRILL

Joonis 1.'aprill' eesti viipekeeles, vt ka http://lihtsustatudviiped.edu.ee

\subsection{Situatsioon 1: analüüs}

Alustanud filmimist, küsib ema kuupäeva. $N$ vastus näitab, et ta on küsimusest aru saanud, sest ta viipleb vastuseks kuunimetuse. $\mathrm{N}$, kes on õppinud eesti viipekeele lihtsustatud viipeid, on neid veelgi lihtsustanud ja mugandanud. Ta kasutab ühe modaalsusena viibet, mis kaasneb ebatäpselt väljahääldatud sõnaga 'aprill' [apill]. Sama sõna kasutab N kõigi kaheteistkümne kalendrikuu üldistuseks. Enamgi veel: sama sõna tähistab kalendrit kui objekti ning samuti soovi kalendrist kellegagi koos kuupäevi vaadata, et tegevuste/sündmuste toimumisaegu kindlaks teha. ‘Aprill' võib tähendada küsimust millal (kui intonatsioon on tõusev), aga ka vastust küsimusele mis kuupäev on jne.

Voorus 4 tahab ema täpsemalt teada, mitmes kuupäev siis on. Kuna N ei oska numbreid sõnadega väljendada (kuupäeva oskab ta näidata kalendrist, kui see muidugi käepärast on), siis ta kasutab vooruni 13 näomiimikat (mõtlus? ebalus?) ning laseb lõpuks küsijal (emal) ise oma küsimusele vastata.

15. voorus palub ema uuritaval hääldada ka sõna mai, mida N 16 . voorus teebki. 18. voorus kordab ta öeldut koos viipega, kuid see on seesama 'aprilli’ tähistav žest. Sellisel valikul võib olla kaks põhjust:

1) kuna aprilli ja mai viiped on eesti viipekeeles sarnased (vt joonis 2), võivad need olla $\mathrm{N}$-i kontseptuaalse või kujundilise kategoriseerimise võimes üheks sulandunud. Selle põhjuseks, et N moodustab käega märke, mis ei ole teravad ega selgete piirjoontega, võib olla asjaolu, et tema käežestide detailse sooritamise oskus ei ole piisava täpsusega ajus lokaliseeritud;

2) kuna kuunimetust 'aprill' üldistab $\mathrm{N}$ suhtluses kõikidele teistele kuudele tähenduses 'aprill' kui 'kalendrikuu', võib ta ka vastava viipe üldistada maikuule. 


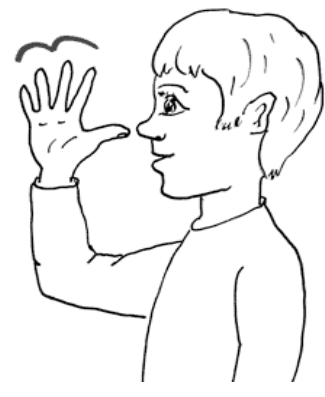

APRILL

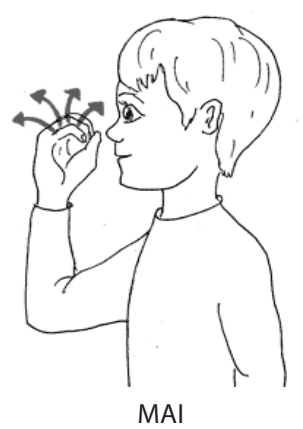

Joonis 2. 'aprill' ja 'mai' eesti viipekeeles, vt ka http://lihtsustatudviiped.edu.ee

\subsection{Situatsioon 2: materjali esitamine}

Dialoog toimus 15 . novembril 2008, kui $\mathrm{N}$ oli 18-aastane. Tegemist on dialoogiga, kus suhtlevad ema (E) ja uuritav subjekt (N). Kuna ema on vahepeal ära olnud, on subjektil palju uudiseid kogunenud ning on märgata tema soovi neid edastada. $\mathrm{N}$ vahetab tihti teemat, püüdes mitut teemat korraga üleval hoida.

Suhtlus toimus N ja ta ema kodus. Ka siin on filmiv osapool - ema - jäänud kaadritaguseks, mistõttu on temalt salvestatud ainult kõnekeelne osa. Lõigu pikkus on 1 minut ja 6 sekundit, sisaldades 28 lausungit.

Situatsiooni kirjeldus: $\mathrm{N}$ on just televiisori sisse lülitanud ja seda natuke aega vaadanud, hoides käsi püksitaskus. Siis tuleb talle meelde sugulase $^{13}$ sünnipäev, ta keerab ennast ema suunas, vaatab talle otsa ja esitab küsimuse.

(2) $1 \mathrm{~N}$ : emme

$$
\begin{array}{ll}
\text { [eabu }] & \text { [emme] eabu emme emme } \\
\text { [nimeviibe } & \text { [nimeviibe }
\end{array}
$$

Tôlge: emme elagu (=sünnipäev) emme elagu emme emme.

Selgitus: Liisal tuleb sünnipäev.

( ( Suhtlust alustades vaatab emale otsa, teise häälitsuse ajal võtab parema käe taskust välja, tõstab kõrgemale ja viipleb sellega kaks korda enda näo kõrgusel. Kasutab viipekeeletunnis loodud viipenime Liisa. ))

$2 \mathrm{E}$ : kas sa räägid liisast või

$3 \mathrm{~N}$ : ea emme eabu emme eabu

Tõlge: jah emme elagu emme elagu

(( Mõlemad käed on uuesti taskus. ))

$4 \mathrm{E}$ : liisa sünnipäev on viieteistkümnendal detsembril

$5 \mathrm{~N}$ : aa ee [aupo] aa

Tõlge: aa ee auto aa

[viibe SEAL]

Selgitus: rääkisime sellest autos kui me seal käisime

(( Osutava žesti sEAL näitamiseks võtab parema käe uuesti taskust välja ja viitab kaugusesse (paremal on klaasuks, kust on kaugele välja näha) ja toob selle siis enda juurde tagasi, pühib silmanurka. ))

/--/

$13 \mathrm{~N}$ : emme eabu

13 Sugulase õige eesnime asemel on transkriptsioonis kasutatud varjunime. 
(( Pöördub samal ajal oma vestluspartneri poole tagasi. ))

14 N: eabu (( valjemalt )) EABU (( veel valjemalt ))

$15 \mathrm{E}$ : kas te liisaga rääkisite autos liisa sünnipäevast

$16 \mathrm{~N}$ : [ee]

$[(($ noogutab $))]$

Tõlge: jah

$17 \mathrm{~N}$ : emme eabu öhö?

viibe LILL

Selgitus: Kas me sünnipäevale lille ka vïme?

( ( Pärast esimese sõna ütlemist kasutab eesti viipekeele viibet LILL - tõstab

käe üles ja näitab avanevat õit. Lausungi lõpus kasutab $\mathrm{N}$ oma universaalset küsisõna öhö?, mille tähendus sõltub öeldava kontekstist ja sellest, milliste žestide, viibete või muude liigutustega seda koos kasutatakse. ))

$18 \mathrm{E}$ : lille peab viima jah

$19 \mathrm{~N}:[\tilde{o} \tilde{o}]$

$[(($ vaevumärgatav noogutus $))]$

$20=\mathrm{N}:$ ühaäe?

Tõlge: pühapäev

Selgitus/tõlgendus: millal see sünnipäev on?

$21 \mathrm{E}$ : see on viieteistkümnendal detsembril

$22 \mathrm{~N}$ : õõ oo aa

Selgitus/tõlgendus: 'oo' võib tähendada 'oota', aga see ei ole 22. voorus väga selge.

(( Hakkab selg ees kummuti poole liikuma. Sirutab enda taha välja parema käe, et kummutisahtlit avada. ))

$23(0.2)$

$23 \mathrm{~N}$ : emme oo emme

Selgitus/tõlgendus: 23. voorus on selgem, et 'oo' tähendab 'oota'.

(( Tõmbab sahtli lahti. ))

24 E: ei see on uus kalender sa pead seina pealt võtma selle kalendri

$25 \mathrm{E}$ : seina pealt saame vaadata kalendrist et mis päev see on

26 N: ühaäe ühaäe

Tõlge: pühapäev

(( Lükkab sahtli kinni ja paneb telekapuldi kummutile. ))

$27 \mathrm{E}$ : seina peal on selle aasta kalender

28 N: (( Märkab kummutil ajakirja ja kaotab teema vastu huvi. ))

\subsection{Situatsioon 2: analüüs}

Videolõigu alguses küsib N sünnipäeva toimumise kohta, andes käežestiga edasi selle inimese viipenime ja kasutades häälistust 'elagu' (tema häälduses eau), mis tähistab sünnipäeva, pigem sünnipäevapidu. Žesti ja lihtsustatud sõna kombineerides moodustab ta fraasi, juhatades sel viisil sisse uue vestlusteema. Siin ei tule veel esile, et ta tahaks väljendada midagi ka sünnipäeva toimumise aja kohta. Edaspidistest voorudest (voor 5) selgub, et ta oli just hiljuti sünnipäevalapsega samal teemal suhelnud (sünnipäevalaps sõidutas teda oma autoga). Voorus 17 väljendab 
$\mathrm{N}$, et lilli tuleb ka viia. Järeldame, et subjektil on olemas teatud suhtlussündmuste teadmine, mingit liiki situatiivne freim. Antud juhul teab ta, et sünnipäev on selline sündmus, mille puhul kingitakse lilli. Vahetult lillede mainimisele järgneb voorus 20 küsimus millal pidu toimub. Küsimuse esitamiseks kasutab ta häälitsust "ühaäe", mis on lihtsustatud variant sõnast 'pühapäev'. Edasi laiendab N teatud ajalise kategooria - kindla nädalapäeva nimetuse - kõigile teistele nädalapäevadele. Tõusev intonatsioon muudab selle häälitsuse küsimuseks. Niisiis on Millal? väljendatud vaid intonatsiooni abil (voor 20). Ema vastab talle, mis kuupäeval pidu toimub. $\mathrm{N}$ läheb kummuti juurde, mille sahtlis on kalender. Ema ütleb, et see on järgmise aasta oma ja sealt ei ole võimalik seda konkreetset kuupäeva leida. Subjekt paneb sahtli kinni. Ta märkab kummutil ajakirja ja ta mõte läheb mujale.

Sünnipäeva-teema arendamisel on mitu põhjust. N tahab teada, millal sünnipäeva peetakse. Ta tahab sinna minna. Ja tahab sel teemal suhelda. Artiklis esitatud situatsioone detailselt analüüsides nägime, et uuritava subjekti žestid, viiped, häälitsused ja kaasnevad prosoodilised vahendid on polüfunktsionaalsed ühe keelevahendi abil väljendab ta erinevaid aspekte. Näiteks viipega LILL (voorus 17) viitab N sünnipäevale, aga see tähendab tal ka konkreetset lille, mille ostmist ei tohi ära unustada. Analüüsi põhjal näeme, et häälikuline osa koos kaasnevate prosoodiliste vahenditega püüab abstraktset mõistet esile tuua. Siinkohal viitame artikli teoreetilises osas toodud sotsiaalse interaktsiooni ja interpersonaalse kommunikatsiooni mõistetele, mis on olulised suhtlusprotsessi uurimisel. Vastasmõjuga suhtluses (interaktsioonis) tuleb selgelt esile, et oma panuse annavad kõik suhtlejad. Vaadeldes teist situatsiooni, näeme, et ilma ühiste (taust)teadmiste ja koostööta ei oleks vestlus õnnestunud.

Kalendri otsimine alates litereeringu 22. reast illustreerib AJA mõiste väljendamist konkreetse objekti abil, milleks on kalender. Aeg on abstraktne tajumuslik kategooria, kalendripäevana aga nähtav ja isegi käegakatsutav. Kuigi juba voorudega 4-21 sai selgeks, et pidu toimub ja millal see on, aitaks kalendri vaatamine uut infot kinnistada.

\section{Arutlus ja kokkuvõte}

Artiklis käsitlesime AJA mõiste konstrueerimist ja esiletulekut erinevate suhtlusmodaalsuste (häälitsused, manipulatsioonid), peamiselt kommunikatiivse žesti abil. Esimese suhtlusepisoodi analüüs näitas, kuidas Patau mosaiikvariandiga subjekt väljendab interaktsioonis žesti abil kalendrikuud 'juuni'. 'Juuni' tähenduseks ja semantilisteks esiletoomiseks kasutab ta pisut ümardatud eesti viipekeele viibet kas 'aprill' või 'mai' - mõlemad tõlgendused on võimalikud. Järeldame, et tegemist on sulandunud tähendusega, sest käeliigutus just sellise tõlgendusvõimaluse annab. Subjekt on teinud ilmse üldistuse või ehk ka järelduse, et kalendrikuu - AJA konkretiseering - tähendab 'aprilli'-laadset viibet. Materjali analüüsist näeme subjekti järeldusvõime kui kognitiivse võime esiletulekut. Subjekti (kalendri)kuu kontsept on esitatud erinevaid kuid tähistava häälitsuse ja ikoonilise žesti kaudu (näitab pika nina märki). Subjekti kognitiivsed võimed (järeldamine, mõiste moodustamine) on interaktsioonis esitatud minimaalselt verbaalse ja peamiselt mitteverbaalse käitumise kaudu. 
Teise suhtlusepisoodi analüüs näitas, et objektiga manipuleerides, häälitsedes ning kommunikatiivsete žestide abil on võimalik Patau mosaiikvariandiga subjektil teha end mõistetavaks ning "vestelda" teemal "Millal on X-i sünnipäev?" Subjektil on oskus näidata kuupäevi kalendrist (manipuleerimine objektiga kui suhtluskäitumise osa).

Esitatud materjali analüüsist nägime, et uuritaval subjektil on AJA väljendamiseks erinevaid vahendeid - need on nii vokaliseeritud, prosoodilised kui ka liigutuslikud ja ta kasutab neid omavahel kombineerides. Samas võib igal tema väljendusvahendil olla mitu tähendust, millest AJAGA seotud kogunevad mõne allkategooria mõiste alla (kalender, kuu(d)).

Analüüsist tuli esile, kuidas N kasutab ema n-ö enda tõlgina, et väljendada seda, mida ta ise sõnastada ei saa. Arvestades sündroomi meditsiinilist lühikirjeldust, on meie analüüs panus Patau sündroomi mosaiikvarinadiga inimeste kognitiivsete võimete täpsustamiseks: $\mathrm{N}$-il on mõistest arusaamise võime, ja mõiste väljendamise võime kommunikatiivsete žestide ja manipulatsioonide abil. Milline on $\mathrm{N}$-i mõiste moodustamise ja täiendavate tähendusseoste loomise mehhanism täpsemalt, pole nende uuringute tulemuste põhjal võimalik öelda.

Inimesed rakendavad AJA mõiste konstrueerimisel oma intuitiivsest maailmanägemisest tulenevaid põhimõtteid. Kui palju sellest annab ette konkreetne keel, selle kohta on vara lõplikke järeldusi teha, kuid kommunikatiivsed võimed on suhtluses - tähenduse loomises ja sellest arusaamises - osa inimese kognitsioonist. Kõnelise suhtlusmodaalsuse puudumine ei takista suhtlemist.

Sõna aeg tähistab inimlikku mõistet, mida iseloomustab vastavus sündmustega ja seotus objektiivse ning subjektiivse ajakäsitlusega. Koos struktureerivad nad meie kogemust ja annavad võimaluse interpersonaalseks suhtluseks.

\section{Lühendid ja transkriptsioonimärgid}

$\mathrm{N} \quad$ uuringu subjekt

$\mathrm{E} \quad$ ema

$\mathrm{V} \quad$ vend

(.) mikropaus: kuni o,2 sekundit

(...) pausi pikkus sekundites

- langev intonatsioon

? tõusev intonatsioon

(( )) transkribeerija kommentaar, tegevuse kirjeldus

$=\quad$ kahe iseseisva üksuse kokkuhääldamine

[ pealerääkimise või samaaegse liigutuse algus

] pealerääkimise või samaaegse liigutuse lõpp

AHA (suurtähed) hääle kõvendamine

$\mathrm{s}(\mathrm{h})$ õna (sulgudes olev $h$ sõna sees) sõna on lausutud naerdes

$\$$......\$ naerva häälega öeldud sõna või pikem lõik, kuid mitte tõeline naer

/--/ transkriptsioonist välja jäetud read 


\section{Viidatud kirjandus}

Bavelas, Janet Beavin; Chovil, Nicole; Lawrie, Douglas A.; Wade, Allan 1992. Interactive gestures. - Discourse Processes, 15, 4, 469-489. doi:10.1080/01638539209544823

Bavelas, Janet Beavin 1994. Gestures as part of speech: methodological implications. Research on Language and Social Interaction. Special Issue on Gestures, 27, 3, 201-221. doi:10.1207/s15327973rlsi2703_3

Bavelas, Janet Beavin; Chovil, Nicole; Coates, Linda; Roe, Lori 1995. Gestures specialized for dialogue. - Personality and Social Psychology Bulletin, 21, 4, 394-405. doi:10.1177/0146167295214010

Berger, Charles R. 2002. Goals and Knowledge Structures in Social Interaction. - Mark L. Knapp, John A. Daly (Eds.). Handbook of Interpersonal Communication. 3rd ed. Thousand Oaks, London, New Delhi: Sage Publications, 181-212.

Berger, Charles R. 2008. Interpersonal Communication. - Wolfgang Donsbach (Ed.). The International Encyclopedia of Communication. Vol. VI. USA, Malden, MA; UK, Oxford; Australia, Carlton, Victoria: Blackwell Publishing Ltd., 2473-2486.

Bruneau, Tom 2009. Chronemics. - Stephen W. Littlejohn, Karen A. Foss (Eds.). Encyclopedia of Communication Theory. Los Angeles, London, New Delhi, Singapore, Washington DC: Sage Reference Publication, 96-101.

Goddard, Cliff 1998. Semantic Analysis. A Practical Introduction. Oxford: Oxford University Press.

Goodwin, Charles 1995. Co-constructing meaning in conversations with an aphasic man. - Research on Language and Social Interaction, 28, 3, 233-260. doi:10.1207/ S15327973rlsi2803 4

Goodwin, Charles 2003. Conversational frameworks for the accomplishment of meaning in aphasia. - Charles Goodwin (Ed.). Conversation and Brain Damage. Oxford: Oxford University Press, 90-116.

Hirsch, Richard 1995. The act of speaking: spoken language and gesture in the determination of definiteness of intention. - C. Pankow (Ed.). Indexicality Papers from the Symposium "Indexikala tecken" and Annual Meeting of the Swedish Society of Semiotics. November 1995. Göteborg: University of Göteborg, 14-30. http://www.sskkii.gu.se/ publications/Documents/html/Indexikality/ (05.03.2011).

Itkonen, Esa 2005. Analogy as Structure and Process: Approaches in Linguistics, Cognitive Psychology and Philosophy of Science. Human Cognitive Processing, 14. Amsterdam, Philadelphia: John Benjamin Publishing Company.

Jokinen, Kristiina; Tenjes, Silvi; Rummo, Ingrid (ilmumas). Embodied interaction and semiotic categorization: communicative gestures of a girl with Patau syndrome. Carita Paradis, Jean Hudson, Ulf Magnusson (Eds.). The Construal of Spatial Meaning: Windows into Conceptual Space. Oxford: Oxford University Press.

Junefelt, Karin 2007. Rethinking Egocentric Speech: Towards a New Hypothesis. New York: Nova Science Publishers.

Kendon, Adam 1995. Gestures as illocutionary and discourse structure markers in Southern Italian conversation. - Journal of Pragmatics, 23, 3, 247-279. doi:10.1016/03782166(94)00037-F

Kendon, Adam 2004. Gesture: Visible Action as Utterance. Cambridge: Cambridge University Press.

Klein, Stefan 2009. Aeg. Aine, millest koosneb elu. Tallinn: Varrak.

Knapp, Mark; Daly, John A.; Albada, Kelly Fudge; Miller, Gerald R. 2002. Background and current trends in the study of interpersonal communication. - Mark L. Knapp, John A. Daly (Eds.). Handbook of Interpersonal Communication. 3rd ed. Thousand Oaks, London, New Delhi: Sage Publications, 3-20.

Koch, Walter A. 2002. Consciousness, communication, speech: A condensed view of the origins of language. - Frank Brisard, Tanja Mortelmans (Eds.). Language and Evolu- 
tion. Antwerp Papers in Linguistics, 101, 39-70.http://webho1.ua.ac.be/apil/apil101/ koch.pdf (15.03.2011).

Littlejohn, Stephen W. 1989. Theories of Human Communication. 3rd ed. Belmont, CA: Wadsworth.

Lotman, Mihhail 2002. Atomistic versus holistic semiotics. - Peeter Torop, Mihhail Lotman, Kalevi Kull (Eds.). Sign Systems Studies, 30, 2. Tartu: Tartu University Press, $513-527$.

Lyons, John 1977. Semantics. Vol. I and II. Cambridge: Cambridge University Press.

Lyons, John 1981. Language and Linguistics. Cambridge: Cambridge University Press.

Marby, Edward A. 2008. Social interaction structure. - Wolfgang Donsbach (Ed.). The International Encyclopedia of Communication, Vol. X. USA, Malden, MA; UK, Oxford; Australia, Carlton, Victoria: Blackwell Publishing Ltd., 4677-4682.

Margolis, Eric; Laurence, Stephen 2006. Concepts. - Keit Brown, Laurie Bauer, Margie Berns, Graeme Hirst, Jim Miller (Eds.). Encyclopedia of Language and Linguistics. 2nd ed. Amsterdam, Boston, Heidelberg, London, New York, etc.: Elsevier, 817-820.

McNeill, David 1992. Hand and Mind: What Gestures Reveal About Thought. Chicago: University of Chicago Press.

Müller, Nicole; Guendouzi, Jacqueline A.; Wilson, Brent 2008. Discourse Analysis and Communication Impairment. - Martin J. Ball, Michael R. Perkins, Nicole Müller, Sara Howard (Eds.). The Handbook of Clinical Linguistics. USA, UK, Australia: Blackwell Publishing Ltd.

Peirce, Charles Sanders 1931-1958. Collected Papers of Charles Sanders Peirce. Vol. 1-8. C. Hartshorne, P. Weiss, A. W. Burks (Eds.). Cambridge, MA: Harvard University Press.

Sacks, Harvey; Schegloff, Emanuel; Jefferson, Gail 1974. A simplest systematics for the organization of turn taking for conversation. - Language, 50, 4, 696-735. doi:10.2307/412243

Streeck, Jürgen; Knapp, Mark L. 1992. The Interaction of Visual and Verbal Features in Human Communication. - F. Poyatos (Ed.). Advances in Nonverbal Communication: Sociocultural, Clinical, Esthetic and Literary Perspectives. Amsterdam/Philadelphia: John Benjamins, 3-24

Varela, Francisco; Thompson, Evan; Rosch, Eleanor 1991. The Embodied Mind: Cognitive Science and Human Experience. Cambridge: The MIT Press.

\section{Võrgumaterjalid}

ICD-10 = International Statistical Classification of Diseases and Related Health Problems. Tenth Revision. http://apps.who.int/classifications/apps/icd/icd1oonline/ (30.09.2010).

Pihol, Liina. Kõnet toetavad ja asendavad lihtsustatud viiped. Päevakeskus Käo. http:// lihtsustatudviiped.edu.ee/ (03.06.2010).

RHK-10 = Rahvusvaheline haiguste klassifikaator. http://www2.sm.ee/rhk/index.asp (03.03.2011).

Ingrid Rummo (Tartu Ülikool) teaduslikud huvialad on suhtlusuuringud kliinilises kontekstis, õppimisvõime mehhanismide bioloogilis-psühholoogilised aspektid, mitteverbaalne suhtlus, žesti- ja viipeuuringud, suuline ja kirjalik tõlge, arvutipõhine keeleõpe. ingrid.rummo@ut.ee

Silvi Tenjes (Tartu Ülikool) on uurinud lingvistika- ja kommunikatsiooniteooriaid, žeste, semantikat ja metafoorsust. Uurib suhtlust multimodaalses kommunikatsioonis. Huvitub tegevusrepresentatsiooni seosest tajuruumiga liigutuste sooritamiseks ning õppimiseks.

silvi.tenjes@ut.ee 


\title{
CONCEPTUALIZATION OF TIME IN THE CONTEXT OF PATAU SYNDROME
}

\author{
Ingrid Rummo, Silvi Tenjes \\ University of Tartu
}

This article studies communication in the context of the mosaic variant of Patau syndrome. The analysis of two sample situations focuses on creating and understanding the concept of TIME. The article discusses the semiotic foundation of communication dimensions (Peirce 1931-1958) as well as its physical basis (Itkonen 2005). The approach is based on discourse analysis and considers semiotic categorization of signs.

The article describes communication possibilities of people with language impairments, in the context of research done on aphasia and conversation by Charles Goodwin $(1995,2003)$. Further, the article introduces discourse analyses in clinical communication studies (Müller, Guendouzi, Wilson 2008). We also give an overview of human cognition and the mosaic variant of Patau syndrome.

Specifically, we examine how an abstract concept (тімE) is formed, presented and forwarded when the traditional communication modality - the ability to speak is missing. The subject $(\mathrm{N})$ comprehends the speech addressed to her, understands everyday topics and questions and is able to answer them, but her means of replying are incomplete. The majority of her communication proceeds by hand and head movements accompanied by sounds. Thus we also consider the role of how gestures are used to bring out meaning in cooperative communication.

The examples are two videotaped communicative situations where the subject of our research is one of the interlocutors. The topic of TIME is present in both of them.

The analysis of the communicative episodes showed that the subject is able to indicate a calendar month (June) using the hand sign for April. However, she visualizes as well as generalizes the name of one month to all the other eleven months. From the discussion we concluded that with the help of communicative gestures, the subject is able to have a "conversation" on the topic When someone's birthday is? while using the hand movement of 'flower' to indicate the event of birthday. She has the ability to communicate and express herself via hand gestures. We also found out that the subject has a certain memory of situations, e.g. a birthday frame and the ability of conceptual categorization, which is mainly expressed via hand movements.

Keywords: discourse analysis, interpersonal communication, communication, nonverbal language, cognition, aphasias, Patau mosaic syndrome 